\title{
Identification and lectotypification of the Solanaceae from Vellozo's Flora Fluminensis
}

Sandra Knapp ${ }^{1}$, Gloria E. Barboza ${ }^{2}$, María Victoria Romero ${ }^{3}$, Marcia Vignoli-Silva ${ }^{4,5}$, Leandro L. Giacomin $^{6,7}$, João Renato Stehmann ${ }^{6}$

1. Department of Life Sciences, Natural History Museum, Cromwell Road, London SW7 5BD,

United Kingdom (author for correspondence: $\underline{\text { s.knapp@nhm.ac.uk) }}$

2. Instituto Multidisciplinario de Biología Vegetal (CONICET-Universidad Nacional de Córdoba),

Casilla de Correo 495, 5000 Córdoba, Argentina

3. Laboratório de Biossistemática e Polinização, Departamento de Biologia Vegetal, Universidade Estadual de Campinas (UNICAMP), Rua Monteiro Lobato 255, Cidade Universitária "Zeferino Vaz" Barão Geraldo, Campinas, CEP 13.083-970, SP, Brazil

4. Programa de Pós-Graduação em Botânica, Universidade Federal do Rio Grande do Sul, Av. Bento Gonçalves 9500, Porto Alegre, CEP 91501-970, RS, Brazil

5. Departamento de Ciências Básicas da Saúde, Universidade Federal de Ciências da Saúde de Porto Alegre, Rua Sarmento Leite 245, CEP 90050-170, Porto Alegre, RS, Brazil

6. Instituto de Ciências Biológicas, Departamento de Botânica, Laboratório de Sistemática Vegetal, Universidade Federal de Minas Gerais - UFMG, Av. Antônio Carlos, 6627, Pampulha, Belo Horizonte, CEP 31270-901, MG, Brazil

7. (current address) Instituto de Ciências e Tecnologia das Águas \& Herbário HSTM, Universidade Federal do Oeste do Pará - UFOPA, Av. Mendonça Furtado, 2946, Santarém, CEP 68040-050, PA, Brazil

\begin{abstract}
We review the sixty eight names of plants treated in genera treated or now recognised as Solanaceae from J.M. da C. Vellozo's Flora Fluminensis in the context of current floristic knowledge of the region around Rio de Janeiro in southern Brazil. Most of Vellozo's names are synonyms of names previously published or are illegitimate later homonyms, but several are accepted and in widespread use. Two names do not belong to solanaceaeous taxa, but to species in Apocynaceae and
\end{abstract}


Violaceae respectively. We provide lectotypifications for all names, including those previously lectotypified using the published plates that do not qualify as original material. Type localities, previous lectotypifications and current accepted names are provided for all taxa.

Key Words: Apocynaceae, Brazil, Brunfelsia, Capsicum, Cestrum, Solandra, Solanum, Violaceae

\section{INTRODUCTION}

The Flora Fluminensis of Brother José Mariano da Conceição Vellozo (1742-1811) was one of the first compilations of names for Brazilian plants, and treated the flora of areas that today are part of Rio de Janeiro and São Paulo states. Vellozo was a parish priest in what is now the city of Rio de Janeiro. The work was begun in 1782, and is organised according to the sexual system of Linnaeus; dates on the title page of the published descriptions indicate the work was completed in 1790 . Effective dates of publication of this work and its accompanying plates are discussed in Carauta (1969, 1973), but delays in publication of the descriptions until 1829 (work dated 1825 but published 7 Sep-28 Nov 1829) meant that many of the names proposed in Flora Fluminensis are illegitimate later homonyms. It is difficult to ascertain in some cases if Vellozo was actually proposing a new name (e.g., Capsicum baccatum Vell., Solanum nigrum Vell. and S. havanense Vell. below) or was using a name already known to him. In the Index to the volumes of illustrations (Vellozo, 1831a) many of these homonyms are identified with marginal notations (e.g., "non Solanum nigrum Linn.”) but with no replacement names provided. We suggest these annotations are the work of Father Antônio de Arrábida and João de Silveira Caldeira, who edited and prepared Vellozo's work for publication (Carauta, 1973). These have no bearing on the status of Vellozo's names, nor are any new names for any Solanaceae introduced in the Index (Vellozo, 1831a). The original descriptions published in 1829 are very short, but are accompanied by references to original illustrations held in the Biblioteca Nacional, Rio de Janeiro that can also be treated as original material for typification of these names (Pellegrini et al., 2015). These illustrations, published two years later in 1831 (work dated 1827 but published 29 Oct 1831), are sometimes incomplete or inaccurate (Lima, 1995; Pastore, 2013). In addition, no herbarium associated with Vellozo's plants has ever been found, although his specimens are thought to have been sent to Lisbon in 1798 (Borgmeier, 1961; Pellegrini et al., 2015) and then possibly to Paris in early 1800s (Lima, 1995). These factors make identification of the species described by Vellozo difficult and many of his names have been treated as problematic and thus ignored.

In the Flora Brasiliensis treatment of Solanaceae, Sendtner (1846) treated all but seven of Vellozo's names; he accepted 17 of them, mentioned four as unrecognisable, and mentioned the rest as either synonyms (29 names) or possible synonyms of other taxa (9 names indicated with “?”). Both 
Bentham (1846) and Schmidt (1862) treated names today recognised as species of Brunfelsia and Schwenckia as part of the "Scrophularieae". Sampaio \& Peckolt (1943) provided a list of all Vellozo's names accompanied by their assessment of the identity of Vellozo's taxa. In many cases they suggested that Vellozo's name was older than the name in use at the time (see individual names below). Much of their synonymy was taken from Sendtner (1846) and Schmidt (1862). None of these later authors referenced the index to the illustration volumes (Vellozo, 1831a) in determining the identity of Vellozo's taxa; only the original descriptions (Vellozo, 1829) and the published plates (Vellozo, 1831a) were cited.

Vellozo described 68 species in genera referable to Solanaceae. Two of these were described in the Linnaean class "Didynamia" as members of the genus Besleria L. (Gesneriaceae). He coined the generic name Mathea Vell., with a single species Mathea apostolica Vell. (a synonym of Schwenckia L. see below), ten names in Capsicum L., three names in Cestrum L., four names in Datura L., one name in Nicotiana L. and 47 names in Solanum L. No new names were proposed in the second edition of Flora Fluminensis (Vellozo, 1881), as is the case in other families (e.g., Leguminosae, see Lima, 1995). All but two of these names are referable to currently recognised species of Solanaceae:

Capsicum torulosum Vell. is a member of Violaceae (most likely Pombalia atropurpureum (St.Hil.) Paula-Souza) and Datura erinacea Vell. is a member of Apocynaceae (Allamanda cathartica L.). Digital images of all original manuscript illustrations are available through the website of the Biblioteca Nacional (http://bndigital.bn.br/acervodigital). Published illustrations from Flora Fluminensis (1831) are available through the Biodiversity Heritage Library (http://www.biodiversitylibrary.org/item/15442\#page/2/mode/1up) and associated with individual names on Solanaceae Source (www.solanaceaesource.org); thus we do not illustrate the lectotypes here.

Where cited by Vellozo (1829), the habitats are very useful in determining the identity of many of these species. Lima (1995) provides a synonymy of Vellozo's habitat designations with current vegetation types recognised in Brazil. Much of the territory covered by the Flora Fluminensis, and therefore many of the collection localities cited in the text, is now part of the city of greater Rio de Janeiro. Some, however, are along the routes from Rio de Janeiro to Sao Paulo, but at the time provincial limits were not well established (Damasceno, 1976), making exact localisation of these citations difficult.

\section{TAXONOMIC TREATMENT}

We list names here in alphabetical order by original name and provide citations to both the descriptions (Vellozo, 1829) and illustrations (Vellozo, 1831b). We cite the habitat and locality 
information from the protologue where available, and locate the type localities in current Brazilian states following Lima (1995). We lectotypify these names using the original material held in the Manuscript Section of the Biblioteca Nacional, Rio de Janeiro; previous lectotypifications using the published illustrations were not done using original material, so these names are all re-lectotypified here. Where lectotypes were previously designated using the published illustrations we cite the work and page. Some of the names treated here will require epitypification to fix current usage - we leave this to monographers of particular groups (e.g., Knapp \& al. accompanying paper; Giacomin \& al., in prep.) as they will be better able to correctly epitypify these taxa in accordance with modern usage. Where Vellozo's names have been equated to other taxa by the editors of the work after his death (see Carauta, 1973) in the Index to the volumes of illustrations (Vellozo, 1831a) we have indicated this accordingly.

Besleria bonodora Vell., Fl. Flumin. 261. 1829 [1825]; Fl. Flumin. Icon. 6: t. 80.1831 [1827].

Lectotype (here designated ): Brazil. [Rio de Janeiro or São Paulo]: no locality or habitat given: [illustration] Original parchment plate of Flora Fluminensis in the Manuscript Section of the Biblioteca Nacional, Rio de Janeiro [cat. no.: mss1198655_084] and later published in Vellozo, Fl. Flumin. Icon. 6: tab. 81. 1831 (published plate designated as lectotype by Plowman, 1998: 59).

Accepted name: Brunfelsia bonodora (Vell.) J.F.Macbr.

Both Bentham (1846) in his monograph of Brunfelsia and Schmidt (1862) in his treatment of the genus for Flora Brasiliensis treated Brunfelsia bonodora as a synonym of B. latifolia (Pohl) Benth. The Index to the illustration volumes (Vellozo, 1831a: 8) lists Besleria bonodora in the "Scrophularieae" and as equivalent to Franciscea acuminata Pohl (=Brunfelsia brasiliensis (Spreng.) L.B.Sm. \& Downs). The usage of Bentham (1846) and Schmidt (1862) was followed (e.g., Sampaio $\&$ Peckolt, 1942) until Macbride (1930) made the combination and used B. bonodora for a complex assemblage of what are now recognised as distinct species (Plowman, 1998).

Besleria inodora Vell., Fl. Flumin. 261. 1829 [1825]; Fl. Flumin. Icon. 6: t. 81.1831 [1827].

Lectotype (here designated): Brazil. [Rio de Janeiro]: "silvis maritimis": [illustration] Original parchment plate of Flora Fluminensis in the Manuscript Section of the Biblioteca Nacional, Rio de Janeiro [cat. no.: mss1198655_085] and later published in Vellozo, Fl.

Flumin. Icon. 6: tab. 81.1831 (published plate designated as lectotype by Plowman, 1989, pg. 103).

Accepted name: Brunfelsia pauciflora (Cham. \& Schltdl.) Benth.

The epithet inodora is not available for use in Brunfelsia because the binomial is preoccupied by Brunfelsia inodora Mart., a synonym of Brunfelsia americana L. (Plowman, 1998). Schmidt 
(1862: 257) treated Besleria inodora as a synonym of Brunfelsia pauciflora (Cham. \& Schltdl.) Benth. var. calycina (Benth.) Benth., while Sampaio \& Peckolt (1943) suggested the correct name was Brunfelsia pauciflora sensu lato.

Mathea apostolica Vell., Fl. Flumin. 22. 1829 [1825]; Fl. Flumin. Icon. 1: t. 51.1831 [1827].

Lectotype (here designated): Brazil. Rio de Janeiro: "Communisima planta camporum haud pinguim hujus continentis, passimque obia quasvis vias Regius": [illustration] Original parchment parchment plate of Flora Fluminensis in the Manuscript Section of the Biblioteca Nacional, Rio de Janeiro [cat. no.: mss1095062_055, as Mathaea apostolica] and later published in Vellozo, Fl. Flumin. Icon. 1: tab. 51. 1831 (published plate designated as lectotype by Carvalho, 1978, pg. 387).

Accepted name: Schwenckia lateriflora (Vahl) Carvalho

Vellozo's illustration of Mathea apostolica is highly inaccurate in showing the two stamens long-exserted from the corolla tube, but otherwise is recognisable as Schwenckia lateriflora. The taxon is listed as a member of "Primulaceae" and as belonging to Schwenkia in the Index to the illustration volumes (Vellozo, 1831b: 8). Schmidt (1862) did not refer to this name in his treatment of Schwenckia for Flora Brasiliensis. Sampaio \& Peckolt (1943) recognised it as belong to the genus Schwenckia, but did not indicate a species.

\section{Capsicum axi Vell., Fl. Flumin. 61. 1829 [1825]; Fl. Flumin. Icon. 2: t. 6.1831 [1827]. Lectotype}

(here designated): Brazil. [Rio de Janeiro]: "Colitur hortis": [illustration] Original parchment parchment plate of Flora Fluminensis in the Manuscript Section of the Biblioteca Nacional, Rio de Janeiro [cat. no.: mss1198651_009] and later published in Vellozo, Fl. Flumin. Icon. 2: tab. 6. 1831 .

Accepted name: Capsicum anпиum L. var. aпnиит

Sendtner (1846:148) treated Capsicum axi as a synonym of Capsicum annuum L. var. cordiforme (Mill.) Sendtn.; the plate is of a large fruited cultivar of the common pepper. In the original parchment illustration the epithet "grossum" is scratched out and replaced with "axi" in pencil. The published illustration is labelled Capsicum axi. We are treating the name Capsicum grossum as not validly published as it has no description or diagnosis associated with it.

Capsicum baccatum Vell., Fl. Flumin. 60. 1829 [1825];Fl. Flumin. Icon. 2: t. 3. 1831 [1827], nom. illeg. non Capsicum baccatum L. (1753). Lectotype (here designated): Brazil. [Rio de Janeiro]: "Sponte crescit, et colitur hortis": [illustration] Original parchment parchment plate of Flora Fluminensis in the Manuscript Section of the Biblioteca Nacional, Rio de Janeiro [cat. no.: mss1198651_006] and later published in Vellozo, Fl. Flumin. Icon. 2: tab. 3. 1831. 
Accepted name: Capsicum frutescens $\mathrm{L}$.

Sendtner treated this, C. comarim and C. odoriferum as synonyms of Capsicum frutescens Willd. (where he also put $C$. frutescens L. in synonymy), with the comment "Species quas Vellozo iconibus refert, huc pertinere videntur sequentes" [the following species from Vellozo's drawings belong here]; Sendtner, 1846: 142).

Capsicum comarim Vell., Fl. Flumin. 60. 1829 [1825]; Fl. Flumin. Icon. 2: t. 2.1831 [1827].

Lectotype (here designated): Brazil. [Rio de Janeiro]: “colitur hortis, et sponte undequaque crescit"; [illustration] Original parchment parchment plate of Flora Fluminensis in the Manuscript Section of the Biblioteca Nacional, Rio de Janeiro [cat. no.: mss1198651_005] and later published in Vellozo, Fl. Flumin. Icon. 2: tab. 2. 1831.

Accepted name: Capsicum baccatum L.

See above under Capsicum baccatum Vell.

Capsicum dichotomum Vell., Fl. Flumin. 61. 1829 [1825]; Fl. Flumin. Icon. 2: t. 9.1831 [1827], as

“Capsicum conicum”; 三 Capsicum conicum Vell., Fl. Flumin. Icon. 2: t. 9.1831 [1827], nom illeg. non Capsicum conicum G.Mey. (1818). Lectotype (here designated): Brazil. [Rio de Janeiro]: “Colitur hortis"; [illustration] Original parchment parchment plate of Flora

Fluminensis in the Manuscript Section of the Biblioteca Nacional, Rio de Janeiro [cat. no.: mss1198651_012] and later published in Vellozo, Fl. Flumin. Icon. 2: tab. 9. 1831.

Accepted name: Capsicum chinense Jacq.

Vellozo used the name Capsicum dichotomum in 1829 and referred to "Tab. 9, T. 2" in the protologue. Both the original parchment illustration and the published plate are labelled Capsicum conicum with no reference to the name C.dichotomum; the reference to the illustration in Vellozo (1829) does, however, unambiguously link these two names as referring to the same taxon. In the second edition (Vellozo, 1881) the name Capsicum dichotomum is also used, with no reference to Capsicum conicum. We are treating these names as homotypic.

Capsicum inaequale Vell., Fl. Flumin. 61.1829 [1825]; Fl. Flumin. Icon. 2: t. 5.1831 [1827].

Lectotype (here designated): Brazil. [Rio de Janeiro]: "fruticetis mediterraneis"; [illustration] Original parchment parchment plate of Flora Fluminensis in the Manuscript Section of the Biblioteca Nacional, Rio de Janeiro [cat. no.: mss1198651_008] and later published in Vellozo, Fl. Flumin. Icon. 2: tab. 5. 1831.

Accepted name: Solanum didymum Dunal

Sendtner recognised this as not belonging to Capsicum ("minima sunt species generis Capsici”; Sendtner, 1846: 148). Sampaio \& Peckolt (1943) left it as an accepted name. From the
Comment [A2]: If the published plates are not considered original material, these names may have different types. It would depend upon the labeling on the original artwork: If 'C. dichotomum', it would be the LT for that name and the published plate would be the LT for ' $C$. conicum'. If the original is labeled 'C. conicum', then it is the LT for that name and either the original or the published plate could be designated as Neotype for $C$. dichotomum.

Comment [A3]: SK comment: I think these two names are unambiguously referring to the same thing..... typifying any Vellozo name on the illustration alone would be crazy. I think our treatment here is perfectly reasonable given the circumstances 
pubescent and enlarged fruiting calyx and the sympodial structure, we consider this a synonym of Solanum didymum, a member of the Brevantherum clade (sensu Bohs, 2007; Särkinen \& al., 2013).

Capsicum odoriferum Vell., Fl. Flumin. 61. 1829 [1825]; Fl. Flumin. Icon. 2: t. 8. 1831 [1827].

Lectotype (here designated): Brazil. [Rio de Janeiro]: “colitur hortis"; [illustration] Original parchment parchment plate of Flora Fluminensis in the Manuscript Section of the Biblioteca Nacional, Rio de Janeiro [cat. no.: mss1198651_011] and later published in Vellozo, Fl.

Flumin. Icon. 2: tab. 8. 1831.

Accepted name: Capsicum chinense Jacq.

See above under Capsicum baccatum Vell.

Capsicum silvestre Vell., Fl. Flumin. 60. 1829 [1825]; Fl. Flumin. Icon. 2: t. 1.1831 [1827]. Type:

Brazil. Rio de Janeiro: “ad declivium Alpium Fluminensium”; [illustration] Original parchment parchment plate of Flora Fluminensis in the Manuscript Section of the Biblioteca Nacional, Rio de Janeiro [cat. no.: mss1198651_004] and later published in Vellozo, Fl. Flumin. Icon. 2: tab. 1. 1831.

Accepted name: Capsicum annuиm L. var. anпиит

In the index to the volumes of plates this species epithet was spelled "sylvestre". Sendtner (1846: 147) treated this Vellozo name as a synonym of the typical Capsicum annuum (with a question mark, indicating his uncertainty), not under one of his infraspecific taxa.

Capsicum torulosum Vell., Fl. Flumin. 60. 1829 [1825]; Fl. Flumin. Icon. 2: t. 4.1831 [1827].

Lectotype (here designated): Brazil. [Rio de Janeiro]: "fruticetis mediterraneis"; [illustration] Original parchment parchment plate of Flora Fluminensis in the Manuscript Section of the Biblioteca Nacional, Rio de Janeiro [cat. no.: mss1198651_007] and later published in Vellozo, Fl. Flumin. Icon. 2: tab. 4. 1831.

Accepted name: NOT SOLANACEAE; Pombalia atropurpureum (St.Hil.) Paula-Souza (Violaceae).

This taxon does not correspond to any species of Solanaceae. In the Index to the illustration volumes of the Flora Fluminensis (Vellozo, 1831a: 14) Capsicum torulosum was listed as belonging to the "Violaceae" and to the genus Ionidium Vent., whose species have recently been treated as the genus Pombalia Vand. (Paula-Souza \& Ballard, 2014). The serrate leaves, opposite phyllotaxy and three-parted capsules suggest Pombalia atropurpureum, a species from Rio de Janeiro, but the flowers depicted in the plate are not Violaceae-like; we thus consider our identification tentative. Sendtner recognised this as not belonging to Capsicum ("minima sunt species generis Capsici"; Sendtner, 1846: 148), but did not suggest what it might be. 
Capsicum umbilicatum Vell., Fl. Flumin. 60. 1829 [1825]; see also Fl. Flumin. Icon. 2: t. 7. 1831

[1827]. Lectotype (here designated): Brazil. [Rio de Janeiro]: "colitur hortis"; [illustration] Original parchment parchment plate of Flora Fluminensis in the Manuscript Section of the Biblioteca Nacional, Rio de Janeiro [cat. no.: mss1198651_010] and later published in

Vellozo, Fl. Flumin. Icon. 2: tab. 7. 1831.

Accepted name: Capsicum baccatum L. var. umbilicatum (Vell.) Hunz. \& Barboza

This variety of Capsicum baccatum is still commonly sold in Brazilian markets and is a cultigen. The plate clearly shows the unusual fruit shape. Sendtner (1846: 147) treated it as a synonym of Capsicum annuum L. var. grossum Sendtn.

Cestrum arvense Vell., Fl. Flumin. 101. 1829 [1825]; Fl. Flumin. Icon. 3: t. 7.1831 [1827].

Lectotype (here designated): Brazil. [Rio de Janeiro or São Paulo]: “campis apricis translapinis, prope Praedium Boavista"; [illustration] Original parchment plate of Flora

Fluminensis in the Manuscript Section of the Biblioteca Nacional, Rio de Janeiro [cat. no.: mss1198652_010] and later published in Vellozo, Fl. Flumin. Icon. 3: tab. 7. 1831. Accepted name: Probably Cestrum axillare Vell.

The unusual inflated corolla tube base both described and depicted by Vellozo is not known in any Brazilian species of Cestrum. Both the plate and description combine the characters of several species, but we think based on the distribution and leaf shape this taxon is conspecific with Cestrum axillare, a quite variable species. Dunal (1852) treated it as "Species omino dubiae, indescriptae" and it was an accepted name in the list of Sampaio \& Peckolt (1943). The yellow flowers could also mean it refers to a cultivated plant of Cestrum parqui L'Her., but the flowers in the plate lack the pedicel typical of that species.

Cestrum axillare Vell., Fl. Flumin. 101. 1829 [1825]; Fl. Flumin. Icon. 3: t. 6.1831 [1827].

Lectotype (here designated): Brazil. [Rio de Janeiro]: “campis mediterraneis”; [illustration] Original parchment parchment plate of Flora Fluminensis in the Manuscript Section of the Biblioteca Nacional, Rio de Janeiro [cat. no.: mss1198652_009] and later published in

Vellozo, Fl. Flumin. Icon. 3: tab. 6. 1831.

Accepted name: Cestrum axillare Vell.

This widely distributed species is distinguished by leaves with prominent secondary veins and axillary, stalked inflorescences, both these features are very apparent in the plate (Vellozo, 1831b). In Brazilian herbaria, it was commonly identified as C. laevigatum Schltdl., a name treated as a synonym of C. axillare by Vignoli-Silva (2009). It was not mentioned in the list of Sampaio \& Peckolt (1943). 
Cestrum stipulatum Vell., Fl. Flumin. 101. 1829 [1825]; Fl. Flumin. Icon. 3: t. 5.1831 [1827].

Lectotype (here designated): Brazil. [Rio de Janeiro]: "habitat silvis maritimis, ac mediterraneis"; [illustration] Original parchment parchment plate of Flora Fluminensis in the Manuscript Section of the Biblioteca Nacional, Rio de Janeiro [cat. no.: mss1198652_008] and later published in Vellozo, Fl. Flumin. Icon. 3: tab. 5. 1831.

Accepted name: Cestrum bracteatum Link \& Otto

Vellozo's plate clearly shows the leafy inflorescences of Cestrum bracteatum and was treated as a synonym of it by Sendtner (1846) and Soares \& al. (2007). Dunal (1852) also mentioned it in the synonymy of $C$. bracteatum, but also treated it as "Species omino dubiae, indescriptae"; it was not mentioned in the list of Sampaio \& Peckolt (1943).

Cestrum subsessile Vell., Fl. Flumin. 102. 1829 [1825]; Fl. Flumin. Icon. 3: t. 8.1831 [1827], nom utique rej. prop.. Lectotype (here designated): Brazil. [Rio de Janeiro]: "silvis maritimis, aliquando ad Praedium sepes"; [illustration] Original parchment parchment plate of Flora Fluminensis in the Manuscript Section of the Biblioteca Nacional, Rio de Janeiro [cat. no.: mss1198652_011] and later published in Vellozo, Fl. Flumin. Icon. 3: tab. 8. 1831.

Accepted name: Cestrum schlechtendalii G.Don

Sendtner (1846) put Cestrum subsessile with a question mark (“?”) in synonymy with his own Cestrum schottii Sendtn. that he recognised as distinct from Cestrum schlechtendalii. Dunal (1852) also mentioned it in the synonymy of $C$. schottii, but also treated it as "Species omino dubiae, indescriptae"; it was not mentioned in the list of Sampaio \& Peckolt (1943). Vignoli-Silva (2009) pointed out differences in the flower morphology (nodding versus erect flowers) of $C$. subsessile and C. schlechtendalii, but left $C$. subsessile as a doubtful name. We have proposed this name for suppression (Knapp \& al., 2015b).

Datura erinacea Vell., Fl. Flumin. 70. 1829 [1825]; Fl. Flumin. Icon. 2: t. 46.1831 [1827]. Lectotype

(here designated): Brazil. [Rio de Janeiro]: "Offendi silvis, aque sunt trans Cautes Cairuassú dictas"; [illustration] Original parchment parchment plate of Flora Fluminensis in the Manuscript Section of the Biblioteca Nacional, Rio de Janeiro [cat. no.: mss1198651_049] and later published in Vellozo, Fl. Flumin. Icon. 2: tab. 46. 1831.

Accepted name: NOT SOLANACEAE. Allamanda cathartica L. (Apocynaceae)

The opposite leaves and spiky fruit of the plant clearly show this is a drawing of the commonly cultivated Brazilian apocynaceous plant Allamanda L. In the Index to the illustrations (Vellozo, 1831a: 11) this name is listed under the "Asclepideae et Apocyneae" and as belonging to the genus Allamanda. In the Flora Brasiliensis treatment of Apocynaceae, Müller-Argovensis (1860) did not mention Datura erinacea in the synonymy or discussion of Allamanda cathartica. 
Datura stramonium Vell., Fl. Flumin. 69. 1829 [1825]; Fl. Flumin. Icon. 2: t. 43.1831 [1827], nom.

\section{|illeg.|non Datura stramonium L. (1753). Lectotype (here designated): Brazil. Rio de} Janeiro: "Pharmacopoli crescit"; [illustration] Original parchment parchment plate of Flora Fluminensis in the Manuscript Section of the Biblioteca Nacional, Rio de Janeiro [cat. no.: mss1198651_046] and later published in Vellozo, Fl. Flumin. Icon. 2: tab. 43. 1831.

Accepted name: Datura stramonium L.

It is not clear if Vellozo (1829) was describing a new species or merely referring to Linnaeus' (1753) Datura stramonium; in the Index to the illustrations it was equated with the Linnaean name (Vellozo, 1831a: 10). Sendtner (1846) treated this as a synonym of Datura stramonium L., as did Sampaio \& Peckolt (1943) who also suggested that Vellozo was referring to the Linnaean species.

Datura arborea Vell., Fl. Flumin. 69. 1829 [1825]; Fl. Flumin. Icon. 2: t. 44.1831 [1827], nom. illeg. non Datura arborea L. (1753). Lectotype (here designated): Brazil. [Rio de Janeiro]: “ad ripas rivulorum tum mediterraneis tum maritimis locis"; [illustration] Original parchment parchment plate of Flora Fluminensis in the Manuscript Section of the Biblioteca Nacional, Rio de Janeiro [cat. no.: mss1198651_047] and later published in Vellozo, Fl. Flumin. Icon. 2: tab. 44. 1831.

Accepted name: Brugmansia suaveolens (Willd.) Bercht. \& C. Presl.

It is not clear if Vellozo (1829) was describing a new species or merely referring to Linnaeus' (1753) Datura arborea. In the Index to the illustrations it was listed as belonging to the genus Brugmansia, and as distinct from Datura arborea L. (Vellozo, 1831a: 10). Sendtner (1846) treated this as a synonym of Datura arborea L., as did Sampaio \& Peckolt (1943) who suggested that Vellozo was referring to the Linnaean species. Brugmansia arborea (L.) Steud., however, does not occur in Brazil; Vellozo's illustration corresponds to a very similar species, B. suaveolens, naturalized in southeastern Brazil, commonly growing along streams and wet places.

Datura scandens Vell., Fl. Flumin. 69. 1829 [1825]; Fl. Flumin. Icon. 2: t. 45.1831 [1827].

Lectotype (here designated): Brazil. [Rio de Janeiro]: "silvis maritimis"; [illustration] Original parchment plate of Flora Fluminensis in the Manuscript Section of the Biblioteca Nacional, Rio de Janeiro [cat. no.: mss1198651_048] and later published in Vellozo, Fl. Flumin. Icon. 2: tab. 45. 1831 (published plate designated as lectotype by Bernadello \& Hunziker, 1987, pg. 648).

Accepted name: Solandra grandiflora Sw.

Sendtner (1846) treated this as a synonym of Solandra grandiflora, as did the editor of the Index to the illustration volumes (Vellozo, 1831a: 10); Sampaio \& Peckolt (1943) treated Datura
Comment [A4]: Did Vellozo habitually cite authors? If not, it's not clear why this should be anything but a use of Linnaeus' name for Linnaeus' taxon. Doesn't 'pharmacopoli crescit' mean the plant was growing in a medicinal herb garden? And not naturally?

Comment [A5]: SK response - I completely disagree with this interpretation - there is NO internal evidence that Vellozo was citing previously published names, and Pharmacopolis is a place name, not a reference to medicinal use. I have discussed this with Charlie Jarvis and we both feel it is safer to not assume Vellozo was doing one thing or the other 
scandens as an accepted name. The combination Solandra scandens (Vell.) Toledo (Handro, 1953) based on Vellozo's plate is superfluous and illegitimate as Solandra scandens Willd. has priority and is based on a different type; Bernardello \& Hunziker (1987) failed to cite this older name.

Nicotiana ruralis Vell., Fl. Flumin. 76. 1829 [1825]; see also Fl. Flumin. Icon. 2: t. 72.1831 [1827].

Lectotype (here designated): Brazil. [São Paulo]: "ad praedium derelictum ad vulgo Parição Paratyenses trans Alpes via, qua ad Oppidum Cunha ducitur"; [illustration] Original parchment plate of Flora Fluminensis in the Manuscript Section of the Biblioteca Nacional, Rio de Janeiro [cat. no.: mss1198651_075] and later published in Vellozo, Fl. Flumin. Icon.

2: tab. 72.1831 (published plate designated as lectotype by Coccuci, 2013, pg. 82). Accepted name: Nicotiana langsdorffii Weinm.

This is a common species in the area of Flora Fluminensis, and the plate and description are clearly of $N$. langsdorffii, published in Roemer \& Schultes (1819: 323) using a description attributed to Johann Anton Weinmann.

Nicotiana tabaccum Vell., Fl. Flumin. 76. 1829 [1825]; see also Fl. Flumin. Icon. 2: t. 71.1831

[1827], nom. illeg. non Nicotiana tabacum L. (1753).. Lectotype (here designated): Brazil: "sponte crescit silvis tum maritimis, tum mediterraneis recenter cultis"; [illustration] Original parchment plate of Flora Fluminensis in the Manuscript Section of the Biblioteca Nacional, Rio de Janeiro [cat. no.: mss1198651_074] and later published in Vellozo, Fl. Flumin. Icon. 2: tab. 71. 1831

Accepted name: Nicotiana tabacum L.

Vellozo's use of this name is most likely in its Linnaean sense, but there is no evidence either in the text or illustrations that $N$. tabacum L. is the taxon intended. The illustration is of a large-leaved cultivar of $N$. tabacum, which Vellozo (1829: 76) remarks is much used in the district.

\section{Solanum ambrosiacum Vell., Fl. Flumin. 90.1829 [1825]; Fl. Flumin. Icon. 2: t. 131. 1831 [1827].} nom utique rej. prop. Lectotype (here designated): Brazil. Rio de Janeiro: “inter gramina Regii Praedii S. Crucis crescit"; [illustration] Original parchment plate of Flora Fluminensis in the Manuscript Section of the Biblioteca Nacional, Rio de Janeiro [cat. no.: mss1198651_134] and later published in Vellozo, Fl. Flumin. Icon. 2: tab. 131. 1831. Accepted name: Solanum viarum Dunal

Sendtner (1846) accepted S. ambrosiacum, and mentioned its similarity to what he was recognising as $S$. aculeatissimum Jacq. (Sendtner's concept included many of the members of section Acanthophora Dunal now recognised as distinct); Nee (1974) treated S. ambrosiacum as a dubious name. The solitary berry suggests this could be a poorly illustrated plant of $S$. palinacanthum Dunal or 
S. capsicoides All. but as the description mentions "Fructus flavescens, odoratissimus. Clysteribus rusticani frequenter utantur" [yellow fragrant fruit used as a purgative by the peasants] and a common name of "Joá amarelo", we consider this name to apply to the species currently called S. viarum, one of the few Brazilian species of section Acanthophora with attenuate-based leaves like those depicted in Vellozo's plate. Mature fruits of S. viarum are yellow and although solitary berries are not common, young weedy plants often produce fruit from few-flowered inflorescences. We therefore propose this name for suppression (Knapp \& al., 2015b).

Solanum arrebenta Vell., Fl. Flumin. 89. 1829 [1825]; Fl. Flumin. Icon. 2: t. 127. 1831 [1827].

Lectotype (here designated): Brazil. [Rio de Janeiro or São Paulo]: [no locality or habitat given]; [illustration] Original parchment plate of Flora Fluminensis in the Manuscript Section of the Biblioteca Nacional, Rio de Janeiro [cat. no.: mss1198651_130] and later published in Vellozo, Fl. Flumin. Icon. 2: tab. 127. 1831.

Accepted name: Solanum capsicoides All.

Sendtner (1846: 59) treated this as a synonym of his concept of Solanum aculeatissimum Jacq., which was extremely broad. Recent authors (Nee, 1974; Mentz \& Oliveira, 2004) have all treated it as a synonym of $S$. capsicoides.

Solanum bifissum Vell., Fl. Flumin. 86. 1829 [1825]; Fl. Flumin. Icon. 2: t. 111. 1831 [1827], nom.

illeg. Lectotype (here designated): Brazil. [Rio de Janeiro]: "campis apricis mediterraneis"; [illustration] Original parchment plate of Flora Fluminensis in the Manuscript Section of the Biblioteca Nacional, Rio de Janeiro [cat. no.: mss1198651_114] and later published in Vellozo, Fl. Flumin. Icon. 2: tab. 111. 1831.

Accepted name: Solanum velleum Thunb.

Vellozo used the name Solanum bifissum for two different taxa, making them both illegitimate. Steudel (1841) proposed the replacement name $S$. spectabile for the second instance of $S$. bifissum (see below) and accepted the first (Steudel, 1841: 601). Sendtner (1846: 54) placed this instance of S. bifissum in synonymy (with a question mark) with his $S$. sordidum Sendtn. var. fulvum Sendtn., now considered a synonym of $S$. subumbellatum Vell. Based on the distribution and the depiction of flowers with the anthers distinctly separate and abundant interpetalar tissue we feel this name is more correctly placed in the synonymy of $S$. velleum, although it could be any one of several similar species of that species group.

Solanum bifissum Vell., Fl. Flumin. 90. 1829 [1825]; Fl. Flumin. Icon. 2: t. 129. 1831 [1827], nom. illeg. $\equiv$ Solanum spectabile Steud., Nomencl. Bot. ed. 2, 2: 600. 1841. Lectotype (here 
designated): Brazil. [Rio de Janeiro]: "tum maritimis tum mediterraneis"; [illustration] Original parchment plate of Flora Fluminensis in the Manuscript Section of the Biblioteca Nacional, Rio de Janeiro [cat. no.: mss1198651_132] and later published in Vellozo, Fl.

Flumin. Icon. 2: tab. 129. 1831.

Accepted name: Solanum vaillantii Dunal

Steudel's (1841) replacement name for this second instance of S. bifissum in Flora Fluminensis is now considered a synonym of $S$. vaillantii. The plate in Vellozo (1831) is clearly that species. Sendtner (1846) accepted S. spectabile.

Solanum bullatum Vell., Fl. Flumin. 84. 1829 [1825]; Fl. Flumin. Icon. 2: t. 104. 1831 [1827].

Lectotype (here designated): Brazil. [Rio de Janeiro]: "silvis maritimis"; [illustration]

Original parchment plate of Flora Fluminensis in the Manuscript Section of the Biblioteca

Nacional, Rio de Janeiro [cat. no.: mss1198651_107] and later published in Vellozo, Fl.

Flumin. Icon. 2: tab. 104. 1831.

Accepted name: Solanum bullatum Vell.

Solanum bullatum has long been an accepted name for a common species in southern Brazil. Sendtner (1846: 42) pointed out that the species did not have bullate leaves ("sed quid sit "bullati" in specie nec tabula nec specimina docent" - neither the plate nor specimens of this species have bullate leaves), but did not change the name (as he did for other plants where he considered the name inappropriate - see S. oleraceum Vell. below). Mentz \& Oliveira (2004) also comment on the application of this name to a set of similar but distinct species. An epitype will be designated as part of an upcoming monographic study of this group (Giacomin \& al., in prep.).

\section{Solanum caavurana Vell., Fl. Flumin. 86. 1829 [1825]; Fl. Flumin. Icon. 2: t. 112.1831 [1827].}

Lectotype (here designated): Brazil. [Rio de Janeiro]: "Undequaque crescit, praecipue silvis excultis"; [illustration] Original parchment plate of Flora Fluminensis in the Manuscript Section of the Biblioteca Nacional, Rio de Janeiro [cat. no.: mss1198651_115] and later published in Vellozo, Fl. Flumin. Icon. 2: tab. 112. 1831 (published plate designated as lectotype by Knapp, 2002, pg. 84).

Accepted name: Solanum caavurana Vell.

Vellozo's illustration of this species shows the large petaloid calyx lobes characteristic of $S$. caavurana. The epithet comes from the native name for this plant, used as a bleaching agent and probably in the treatment of fever (Vellozo, 1829). Aureliana fasciculata (Vell.) Sendtn. (see below) is also sometimes called 'caavurana' (Hunziker \& Barboza, 1991), but does not have the petaloid calyx lobes depicted in Vellozo's (1831b) plate. 
Solanum caeruleum Vell., Fl. Flumin. 86. 1829 [1825]; Fl. Flumin. Icon. 2: t. 110. 1831 [1827].

Lectotype (here designated): Brazil. [Rio de Janeiro]: "silvis excultis mediterraneis"; [illustration] Original parchment plate of Flora Fluminensis in the Manuscript Section of the Biblioteca Nacional, Rio de Janeiro [cat. no.: mss1198651_113] and later published in Vellozo, Fl. Flumin. Icon. 2: tab. 110. 1831 (published plate designated as lectotype by Knapp, 2002,pg. 87).

Accepted name: Solanum campaniforme Roem. \& Schult.

This name was treated as accepted by Sendtner (1846). The illustration in Vellozo (1831b) shows the characteristic long, sometimes branched inflorescences, deeply divided corollas and relatively narrow leaves of the widespread species $S$. campaniforme. If northern and southern populations of this widespread and polymorphic species are recognised as distinct, S. caeruleum would be the correct name to apply to the southern plants.

Solanum cernuum Vell., Fl. Flumin. 84. 1829 [1825]; Fl. Flumin. Icon. 2: t. 103. 1831 [1827].

Lectotype (here designated): Brazil. [Rio de Janeiro]: "Habitat silvis et campis maritimis, et mediterraneis, praecipue excultis"; [illustration] Original parchment plate of Flora Fluminensis in the Manuscript Section of the Biblioteca Nacional, Rio de Janeiro [cat. no.: mss1198651_106] and later published in Vellozo, Fl. Flumin. Icon. 2: tab. 103. 1831

(published plate designated as lectotype by Carvalho, 1996, pg. 22).

Accepted name: Solanum cernuиm Vell.

With the long, branched, densely pubescent inflorescences and large repand leaves the illustration of $S$. cernuum is a good match for plants recognised as this species. Distinguishing this from the closely related and very similar $S$. castaneum Carvalho can be difficult and an epitype will be proposed in an upcoming monograph (Giacomin \& al., in prep.) in order to aid with the interpretation of the stylistic Vellozo (1831b) illustration.

\section{Solanum congestum Vell., Fl. Flumin. 82. 1829; Fl. Flumin. Icon. 2: t. 90. 1831 [1827]. Lectotype}

(here designated): Brazil. [Rio de Janeiro]: “campis apricis habitat”; [illustration] Original parchment plate of Flora Fluminensis in the Manuscript Section of the Biblioteca Nacional, Rio de Janeiro [cat. no.: mss1198651_093] and later published in Vellozo, Fl. Flumin. Icon. 2: tab. 90.1831.

Accepted name: Acnistus arborescens (L.) Schltdl.

Although the flowers on the plate from Vellozo (1831b) are morphologically drawn like those of a Solanum with a central boss of five connivent stamens, the description and the rest of the plant are more like the common second growth shrub Acnistus arborescens, with greenish white flowers in congested fascicles. Sendtner (1846: 57) treated this name as dubious and listed it under a section 
entitled "Icones Florae Fluminensis et scientiae botanicae et artis defectum saepe parae ferentes de speciebus nos incertos reliquerunt, quae sequuntur" (Illustrations from Flora Fluminensis that are both botanically and artistically lacking that leave us uncertain as to their identity).

Solanum conicum Vell., Fl. Flumin. 2: 83. 1829 [1825]; Fl. Flumin. Icon. 2: t. 96. 1831, nom. illeg. non Solanum conicum Ruiz \& Pav. (1799); इ Solanum fluminense Steud., Nomencl. Bot. ed 2, 2: 602. 1841. Lectotype (here designated): Brazil. [Rio de Janeiro]: "campis apricis mediterraneis ad Praedium derelictum vulgo dictum Parição"; [illustration] Original parchment plate of Flora Fluminensis in the Manuscript Section of the Biblioteca Nacional, Rio de Janeiro [cat. no.: mss1198651_099] and later published in Vellozo, Fl. Flumin. Icon. 2: tab. 96.1831 (published plate designated as lectotype by Bohs, 1995, pg. 152). Accepted name: Not identifiable to a particular species, could be one of several members of the Cyphomandra clade (Bohs, 2007).

Many species of southern Brazilian members of the Cyphomandra clade are very similar morphologically and are distinguished by details of stigma and anther morphology, not apparent in Vellozo's (1831b) very stylized plate. In the Index to the illustrations (Vellozo, 1831a: 10) this name is listed as being a member of the genus Witheringia L'Hér. The Lista de Espécies da Flora do Brasil (Stehmann \& al. 2014) treats this name as ambiguous under Solanum. In her monograph of Cyphomandra Bohs (1994: 152) considered this name as dubious and thought it could be a depiction of S. sciadostylis (Sendtn.) Bohs, S. calycina (Sendtn.) Bohs or S. diploconos (Mart.) Bohs (as Cyphomandra sciadostylis, C. calycina and C. diploconos (Mart.) Sendtn.). Steudel (1841) proposed the replacement name $S$. fluminense and recognized S. conicum Ruiz \& Pav. as distinct.

Solanum cormanthum Vell., Fl. Flumin. 86. 1829 [1825]; Fl. Flumin. Icon. 2: t. 113. 1831 [1827].

Lectotype (here designated):Brazil. Rio de Janeiro: "silvis maritimis Regii Praedii S.

Crucis"; [illustration] Original parchment plate of Flora Fluminensis in the Manuscript Section of the Biblioteca Nacional, Rio de Janeiro [cat. no.: mss1198651_116] and later published in Vellozo, Fl. Flumin. Icon. 2: tab. 113. 1831 (published plate designated as lectotype by Knapp \& al., 2015a, pg. 24).

Accepted name: Solanum lacteum Vell.

Knapp \& al. (2015a) consider the plate of $S$. cormanthum to represent a flowering specimen of the same taxon as S. lacteum. Sendtner (1846) used the name S. cormanthum for some sterile specimens (now at BR) from Minas Gerais with reservations; these highly endemic plants could not be that represented by Vellozo's species, said to come from near the coast in Rio de Janeiro. 
Solanum coronatum Vell., Fl. Flumin. 82. 1829 [1825]; Fl. Flumin. Icon. 2: t. 92. 1831, nom. utique rej. prop. Lectotype (here designated): Brazil. São Paulo: “campis apricis mediterraenis ad viam, qua ducitur ad oppidum Cunha"; [illustration] Original parchment plate of Flora Fluminensis in the Manuscript Section of the Biblioteca Nacional, Rio de Janeiro [cat. no.: mss1198651_095] and later published in Vellozo, Fl. Flumin. Icon. 2: tab. 92. 1831. Accepted name: Solanum rufescens Sendtn. or Solanum capoerum Dunal

The telegraphic description and highly stylized illustration make this name impossible to apply. Sendtner (1846: 38) included it in the synonymy of S. sambuciflorum Sendtn. with a question mark; he also commented that his species was like $S$. coronatum "huic simile glabritie et inflorescentia minus divaricate recedit" (similar but with a more branched and glabrous inflorescence). Sampaio \& Peckolt (1943) followed this usage. We have proposed this name for suppression (Knapp \& al., 2015b).

Solanum cylindricum Vell., Fl. Flumin. 2: 87. 1829; Fl. Flumin. Icon. 2: t. 119. 1831 [1827].

Lectotype (here designated): Brazil. [Rio de Janeiro]: “campis apricis mediterraneis";

[illustration] Original parchment plate of Flora Fluminensis in the Manuscript Section of the Biblioteca Nacional, Rio de Janeiro [cat. no.: mss1198651_122] and later published in Vellozo, Fl. Flumin. Icon. 2: tab. 119. 1831 (published plate designated as lectotype by

Chiarini, 2013, pg. 170).

Accepted name: Solanum cylindricum Vell.

Bohs (2001) accepted both $S$. cylindricum and S. ellipticum Vell. as being part of her broad circumscription of S. cylindricum, a member of section Cyphomandropsis (the Cyphomandra clade of Bohs, 2007). She did not designate lectotypes for either of these names. The species does not occur in the region covered by Flora Fluminensis other than from cultivated plants. The circumscription of Bohs (2001) comprises plants mostly from Santa Catarina and Paraná states. Mentz \& Oliveira (2004) did not include this name, but did include S. ellipticum (a synonym of $S$. cylindricum) as $S$. johannae Bitter (see below).

Solanum decurrens Vell., Fl. Flumin. 89. 1829 [1825]; Fl. Flumin. Icon., t. 126. 1831, nom. illeg. non Solanum decurrens Balb. (1811); 三Solanum hoehnei C.V. Morton, Contr. U.S. Natl. Herb.

29: 72. 1957. Lectotype (here designated): Brazil. [Rio de Janeiro]: "ad quondam rivulum in silvis Pharmacopolitanis etiam ad ripas fluvii Taguahy silvis Regii Praedii S. Crucis";

[illustration] Original parchment plate of Flora Fluminensis in the Manuscript Section of the Biblioteca Nacional, Rio de Janeiro [cat. no.: mss1198651_129] and later published in Vellozo, Fl. Flumin. Icon. 2: tab. 126. 1831. 
Sendtner (1846) accepted Solanum decurrens in Flora Brasiliensis (as did Sampaio \& Peckolt 1943 ) and the earlier S. decurrens Balb. as a synonym of S. balbisii Dunal (itself an illegitimate superfluous name as $S$. decurrens Balb. is cited in synonymy). Both $S$. balbisii and $S$. decurrens Balb.are synonyms of $S$. sisymbriifolium Lam. Morton (1957) coined the replacement name $S$. hoehnei for Vellozo's $S$. decurrens, but did not designate a lectotype. The Vellozo figure does not show the aculeate stems cited in the description suggesting this could represent the closely related $S$. reptans Bunbury rather than $S$. hoehnei. In view of the morphology and distribution of S. hoehnei we consider it distinct from the very similar S. reptans pending further studies.

Solanum diantherum Vell., Fl. Flumin. 83. 1829 [1825]; Fl. Flumin. Icon. 2: t. 99. 1831, nom. rej. prop. Lectotype (here designated):Brazil. Rio de Janeiro: "habitat silvis maritimis Pharmacopolitanis"; [illustration] Original parchment plate of Flora Fluminensis in the Manuscript Section of the Biblioteca Nacional, Rio de Janeiro [cat. no.: mss1198651_102] and later published in Vellozo, Fl. Flumin. Icon. 2: tab. 99. 1831.

Accepted name: Solanum concinnum Schott ex Sendtn.

Sendtner (1846) treated this name with two question marks as a synonym of Solanum concinnum. We have proposed this name for suppression (Knapp \& al., 2015b).

Solanum diffusum Vell., Fl. Flumin. 83. 1829 [1825]; Fl. Flumin. Icon. 2: t. 98. 1831, nom. illeg. non Solanum diffusum Ruiz \& Pav. (1799). Lectotype (here designated): Brazil. [Rio de Janeiro]: "campis apricis mediterraneis"; [illustration] Original parchment plate of Flora Fluminensis in the Manuscript Section of the Biblioteca Nacional, Rio de Janeiro [cat. no.: mss1198651_101] and later published in Vellozo, Fl. Flumin. Icon. 2: tab. 98. 1831. Accepted name: Solanum paucidens Bitter

This species is a member of the Morelloid clade of Solanum (see Särkinen \& al., 2013), whose species are notoriously difficult to distinguish. From the locality information provided, it is most likely that the plants used to coin this name came from the Serra do Mar, thus making this a synonym of the widespread species $S$. paucidens, rather than of the more restricted, high elevation $S$. enantiophyllanthum Bitter, confined to areas above $2000 \mathrm{~m}$ in the Serra da Mantiequeira and the Serra do Mar.

Solanum diflorum Vell., Fl. Flumin. 84. 1829 [1825]; Fl. Flumin. Icon. 2: t. 102. 1831 [1827].

Lectotype (here designated):Brazil. [Rio de Janeiro]: “campis apricis mediterraneis prope Praedium Boavista"; [illustration] Original parchment plate of Flora Fluminensis in the Manuscript Section of the Biblioteca Nacional, Rio de Janeiro [cat. no.: mss1198651_105] 
and later published in Vellozo, Fl. Flumin. Icon. 2: tab. 102. 1831 (published plate designated as lectotype by Knapp, 2002, pg. 62):

Accepted name: Solanum pseudocapsicum L.

Pubescent plants of $S$. pseudocapsicum from both southern Brazil and Mexico were long called S. diflorum, but Knapp (2002) put these two names in synonymy; Mentz \& Oliveira (2004) followed this usage. Sendtner (1846) and Sampaio and Peckolt (1943) accepted this species as distinct from S. pseudocapsicum.

Solanum edule Vell., Fl. Flumin. 88. 1829 [1825]; Fl. Flumin. Icon. 2: t. 121. 1831, nom. illeg. non Solanum edule Schumach. \& Thonn. (1827). Lectotype (here designated): Brazil. [Rio de Janeiro]: "maritimis raro rescit, mediterraneis frequentissime, praesertim silvis recentur excultis"; [illustration] Original parchment plate of Flora Fluminensis in the Manuscript Section of the Biblioteca Nacional, Rio de Janeiro [cat. no.: mss1198651_124] and later published in Vellozo, Fl. Flumin. Icon. 2: tab. 121. 1831.

Accepted name: Solanum sisymbrifolium Lam.

The deeply pinnatifid leaves and densely prickly stems together with the habitat description of occurrence in abandoned fields and red berries make identification of $S$. edule unambiguous. The epithet coined by Vellozo suggests the fruits were eaten, but he does not mention this, only that the fruits were cherry colored ("Colore cerasa imitantur" - color cherry-like).

Solanum elegans Vell., Fl. Flumin. 2: 83.1829 [1825]; Fl. Flumin. Icon. 2: t. 95. 1831, nom. illeg. non Solanum elegans Dunal (1814); 三 Solanum arrabidae Steud., Nomencl. Bot. ed. 2, 2: 600. 1841; 三 Cyphomandra velloziana Sendtn., Flora 28: 175. 1845. Lectotype (here designated): Brazil. [Rio de Janeiro]: "habitat tum mediterraneis, tum maritimis"; [illustration] Original parchment plate of Flora Fluminensis in the Manuscript Section of the Biblioteca Nacional, Rio de Janeiro [cat. no.: mss1198651_098] and later published in Vellozo, Fl. Flumin. Icon. 2: tab. 95.1831 (published plate designated as lectotype by Bohs, 1994, pg. 152)

Accepted name: Not identifiable to a particular species, could be Solanum premnifolium (Miers) Bohs Species of southern Brazilian members of the Cyphomandra clade are very similar morphologically and are distinguished by details of stigma and anther morphology, not apparent in Vellozo's (1831b) very stylized plate. In her monograph of Cyphomandra Bohs (1994: 152) considered this name as dubious because the details of morphology particular to S. premnifolium such as the slender style and the prominent pedicellar remnants are not visible in Vellozo's (1831b) ilustration. The Lista de Espécies da Flora do Brasil (Stehmann \& al., 2014) lists S. elegans, $S$. 
arrabidae and Cyphomandra velloziana as dubious names. Sendtner (1845: 175) was apparently unaware of Steudel's (1841) epithet, and did not cite it in synonymy of his Cyphomandra velloziana.

Solanum ellipticum Vell., Fl. Flumin. 84. 1829 [1825]; Fl. Flumin. Icon. 2: t. 100. 1831, nom. illeg. non Solanum ellipticum R.Br. (1811); 三Solanum johannae Bitter, Repert. Spec. Nov. Regni Veg. 12: 645. 1913. Lectotype (here designated): Brazil. Rio de Janeiro: "habitat eodem loco, quo praecedens [silvis maritimis Pharmacopolitanis] "; [illustration] Original parchment plate of Flora Fluminensis in the Manuscript Section of the Biblioteca Nacional, Rio de Janeiro [cat. no.: mss1198651_103] and later published in Vellozo, Fl. Flumin. Icon. 2: tab. 100. 1831 (published plate designated as lectotype by Chiarini, 2013, pg. 170): Accepted name: Solanum cylindricum Vell.

Bohs (2001) treats this as a synonym of $S$. cylindricum, despite the lack of specimens from the Rio de Janeiro or São Paulo area (see above) and did not designate a lectotype for this name. Sendtner (1846) treated this and S. cylindricum as members of his genus Cyphomandra as C. elliptica (Vell.) Sendtn. and C. cylindrica (Vell.) Sendtn. respectively. Mentz and Oliveira (2004) treated this species as $S$. johannae, and did not mention the name $S$. cylindricum (see above).

Solanum fasciculatum Vell., Fl. Flumin. 85. 1829 [1825]; Fl. Flumin. Icon. 2: t. 106. 1831 [1827].

Lectotype (here designated): Brazil. [Rio de Janeiro]: "habitat campis apricis mediterraneis"; [illustration] Original parchment plate of Flora Fluminensis in the Manuscript Section of the Biblioteca Nacional, Rio de Janeiro [cat. no.: mss1198651_109] and later published in Vellozo, Fl. Flumin. Icon. 2: tab. 106. 1831 (published plate designated as lectotype by Rodrigues \& Stehmann, 2013, pg. 136).

Accepted name: Aureliana fasciculata (Vell.) Sendtn.

Sendtner (1846: 138) segregated the genus Aureliana Sendtn. from Solanum and included species with fasciculate inflorescences and stamens with free filaments (in contrast to the cymose inflorescences and connivent stamens of Solanum). He suggested that A. fasciculata was a variety of A. lucida (Moric.) Sendtn. That name was used until the two taxa were considered con-specific by Hunziker and Barboza (1991); subsequent authors have maintained this usage (Rodrigues \& Stehmann, 2013; Zamberlan \& al., 2015). Vellozo's epithet predates that of Moricand (1837) by ten years. Aureliana Sendtn. is a later homonym of Aureliana Boehm. (Boehmer, 1760: 283), a synonym of Panax L. (Araliaceae); this has been overlooked by monographers (Hunziker \& Barboza, 1991) and in generic treatments of Solanaceae (e.g., Hunziker, 2000). Recent molecular work (Zamberlan \& al., 2015) has shown Aureliana Sendtn. and Athenaea Sendtn. form a monophyletic group, thus this epithet will need to be transferred to the available and correct generic name Athenaea Sendtn. 
Solanum flaccidum Vell., Fl. Flumin. 87. 1829 [1825]; Fl. Flumin. Icon. 2: t. 115.1831 [1827].

Lectotype (here designated): Brazil. Rio de Janeiro: "habitat silvis maritimis

Pharmacopolim"; [illustration] Original parchment plate of Flora Fluminensis in the

Manuscript Section of the Biblioteca Nacional, Rio de Janeiro [cat. no.: mss1198651_118]

and later published in Vellozo, Fl. Flumin. Icon. 2: tab. 115. 1831 (published plate designated as lectotype by Knapp, 2013: 144).

Accepted name: Solanum flaccidum Vell.

The identification of Vellozo's (1831b) plate with this species is unambiguous. The unequal anthers and broadly cordate leaves of S. flaccidum are clearly depicted. Sendtner (1846) and Sampaio \& Peckolt (1943) accepted this name as have all subsequent authors (e.g., Knapp, 2013).

Solanum gnaphalocarpon Vell., Fl. Flumin. 82. 1829 [1825]; Fl. Flumin. Icon. 2: t. 91.1831 [1827].

Lectotype (here designated): Brazil. [Rio de Janeiro]: "Crescit campis apricis

mediterraneis"; [illustration] Original parchment plate of Flora Fluminensis in the Manuscript Section of the Biblioteca Nacional, Rio de Janeiro [cat. no.: mss1198651_094] and later published in Vellozo, Fl. Flumin. Icon. 2: tab. 91.1831 (published plate designated as lectotype by Knapp, 2002, pg. 272).

Accepted name: Solanum gnaphalocarpon Vell.

The distinctive pubescent berries, anisophyllous sympodial units and small flowers are clearly depicted in Vellozo's plate and this name has long been in unambiguous use (Sendtner, 1846; Knapp, 2002; Mentz \& Oliveira, 2004).

Solanum havanense Vell., Fl. Flumin. 82. 1829 [1825]; Fl. Flumin. Icon. 2: t. 94. 1831, nom. illeg. non Solanum havanense Jacq. (1760). Lectotype (here designated): Brazil. Rio de Janeiro: "silvis maritimis Pharmacopolitanis crescit"; [illustration] Original parchment plate of Flora Fluminensis in the Manuscript Section of the Biblioteca Nacional, Rio de Janeiro [cat. no.: mss1198651_097] and later published in Vellozo, Fl. Flumin. Icon. 2: tab. 94.1831 (published plate designated as lectotype by Knapp, 2008, pg. 414).

Accepted name: Solanum lacteum Vell.

Knapp (2008) included this name in the synonymy of $S$. havanense Jacq., a species confined to the islands of the Caribbean. It is probably the case that Vellozo was applying Jacquin's name to a species from Brazil, rather than coining a new name, but there is no evidence to that effect in the publication. The editor of the Index recognised the homonymy and non-identity of these names (Vellozo, 1831a: 10). Closer examination of the illustration suggests that the name is referring to $S$. lacteum, the distinctive constrictions at the base of the calyx lobes in fruit match that species. Members of the Geminata clade to which these taxa belong are very similar morphologically and are 
difficult to distinguish without good specimens. Sendtner (1846: 57) treated this name as dubious in a section entitles "Icones Florae Fluminensis et scientiae botanicae et artis defectum saepe parae ferentes de speciebus nos incertos reliquerunt, quae sequuntur" (Illustrations from Flora Fluminensis that are both botanically and artistically lacking that leave us uncertain as to their identity).

\section{Solanum hexandrum Vell., Fl. Flumin. 88. 1829 [1825]; Fl. Flumin. Icon. 2: t. 122. 1831 [1827].}

Lectotype (here designated): Brazil. [Rio de Janeiro]: "habitat silvis nondum cultis";

[illustration] Original parchment plate of Flora Fluminensis in the Manuscript Section of the Biblioteca Nacional, Rio de Janeiro [cat. no.: mss1198651_125] and later published in Vellozo, Fl. Flumin. 2: tab. 122. 1831.

Accepted name: Solanum hexandrum Vell.

The very large, usually 6-parted flowers upon which the epithet is based make identification of this taxon unambiguous. Solanum hexandrum was accepted by Sendtner (1846) and others (e.g., Whalen, 1986; Stehmann \& al., 2014).

Solanum inaequale Vell., Fl. Flumin. 87. 1829 [1825]; Fl. Flumin. Icon. 2: t. 116. 1831 [1827].

Lectotype (here designated): Brazil. [Rio de Janeiro]: "habitat silvis maritimis ad ripas fluvii vulgo dicti Taguahy"; [illustration] Original parchment plate of Flora Fluminensis in the Manuscript Section of the Biblioteca Nacional, Rio de Janeiro [cat. no.: mss1198651_119] and later published in Vellozo, Fl. Flumin. Icon. 2: tab. 116. 1831 (published plate designated as lectotype by Knapp, 2002, pg. 114):

Accepted name: Solanum pseudoquina A.St.Hil.

Solanum inaequale was a long-accepted name for this taxon prior to Knapp (2002) who found S. pseudoquina was the older name. The Vellozo name refers to the distinctive unequal anthers of this common species and the type of $S$. pseudoquina is in fruit. Sendtner (1846) accepted S. inaequale as a species distinct from $S$. pseudoquina.

Solanum inodorum Vell., Fl. Flumin. 85. 1829 [1825]; Fl. Flumin. Icon. 2: t. 107. 1831 [1827].

Lectotype (here designated): Brazil. [São Paulo?]: "habitat ad radices Alpium

Paratyensium"; [illustration] Original parchment plate of Flora Fluminensis in the Manuscript Section of the Biblioteca Nacional, Rio de Janeiro [cat. no.: mss1198651_110] and later published in Vellozo, Fl. Flumin. Icon. 2: tab. 107. 1831 (published plate designated as lectotype by Knapp, 2013, pg. 154).

Accepted name: Solanum inodorum Vell.

Solanum inodorum is a distinctive species and is easily recognised from the plate based on its pseudoaxillary inflorescences and exfoliating bark (Knapp, 2013). Knapp (2013) incorrectly cited the 
state of Rio de Janeiro as the type locality, while the collection was more probably from the state of São Paulo.

Solanum jubeba Vell., Fl. Flumin. 89. 1829 [1825]; Fl. Flumin. Icon. 2: t. 124. 1831 [1827].

Lectotype (here designated): Brazil. [Rio de Janeiro]: "habitat campis apricis mediterraneis apricis"; [illustration] Original parchment plate of Flora Fluminensis in the Manuscript Section of the Biblioteca Nacional, Rio de Janeiro [cat. no.: mss1198651_127] and later published in Vellozo, Fl. Flumin. Icon. 2: tab. 124. 1831 (published plate designated as lectotype by Chiarini, 2013, pg. 225).

Accepted name: Solanum insidiosum Mart.

Index Kewensis (now available at IPNI, www.ipni.org) lists the name Solanum juripeba Vell. ex Steud. (Nomencl. Bot. ed. 2, 2: 603. 1841), but we can find no such name proposed in Steudel's work. Steudel (1841: 603) cites a "juripeba Arrab. pycnanthemum" (referring to Father Antônio de Arrábida, one of the editors of Vellozo's work) but no species "S. juripeba" occurs in Vellozo's work either in the descriptions, plates or later index; it is possible that this is a misprint or misinterpretation of Vellozo's S. jubeba. "Juripeba" or "jurubeba" is the common name for many spiny solanums in Brazil, but is only used by Vellozo (1829: 90) for his second instance of S. bifissum (see above). Sampaio and Peckholt (1937) suggested that Vellozo's S. jubeba should be the accepted name for $S$. insidiosum Mart. (an accepted species in the Erythrotrichum group that also includes $S$. pycnanthemum Sendtn., the species cited by Steudel; Agra, 2004). Chiarini (2013) listed the species in the synonymy of $S$. paniculatum L., but the entire, apparently glabrescent leaves with strong threeparted venation from the base, elongate thin buds and deeply lobed corolla depicted by Vellozo fit better with plants of $S$. insidiosum and we do not agree with the treatment of $S$. jubeba in the syunonymy of $S$. paniculatum. We propose this name for suppression (Knapp \& al., 2015b).

Solanum lacteum Vell., Fl. Flumin. 82. 1829 [1825]; Fl. Flumin. Icon. 2: t. 93.1831 [1827].

Lectotype (here designated): Brazil. [Rio de Janeiro]: "silvis nondum cultis ad rivulos, vel stagna crescit"; [illustration] Original parchment plate of Flora Fluminensis in the Manuscript Section of the Biblioteca Nacional, Rio de Janeiro [cat. no.: mss1198651_096] and later published in Vellozo, Fl. Flumin. Icon. 2: tab. 93.1831 (published plate designated as lectotype by Knapp \& al., 2015a, pg. 24); epitype designated by Knapp \& al. (2015a). Accepted name: Solanum lacteum Vell.

Solanum lacteum is a member of the Geminata Clade, a group of glabrous forest species difficult to distinguish without good specimens (Knapp, 2002; Knapp \& al., 2015a). Vellozo (1827) described several members of this clade and though some of the names have long been in use (e.g., $S$. caavurana, S. gnaphalocarpon) this is one that was treated as probably referring to a member of the 
genus Aureliana by Knapp (2002). It was resurrected by Stehmann \& al. (2014) to refer to small shrubs with few flowers in tight clusters with white inflorescence axes; we retain that usage here.

Solanum multiangulatum Vell., Fl. Flumin. 91. 1829 [1825]; Fl. Flumin. Icon. 2: t. 133. 1831, nom rej. prop. Lectotype (here designated): Brazil. [Rio de Janeiro]: "habitat silvis maritimis, et mediterraneis"; [illustration] Original parchment plate of Flora Fluminensis in the Manuscript Section of the Biblioteca Nacional, Rio de Janeiro [cat. no.: mss1198651_136] and later published in Vellozo, Fl. Flumin. Icon. 2: tab. 133. 1831.

Accepted name: Possibly Solanum echidnaeiforme Dunal

Although the leaf shape and cauline prickles in Vellozo's plate suggest this represents $S$. echidnaeforme, the calyces are not represented as recovering the corolla in bud, not allowing a precise match, and no other species can be associated with this illustration. We have proposed this name for suppression (Knapp \& al., 2015b).

\section{Solanum nigrum Vell., Fl. Flumin. 85. 1829 [1825]; Fl. Flumin. Icon. 2: t. 109. 1831 [1827].}

Lectotype (here designated): Brazil. [Rio de Janeiro]: “undequaeque nascitur”; [illustration] Original parchment plate of Flora Fluminensis in the Manuscript Section of the Biblioteca Nacional, Rio de Janeiro [cat. no.: mss1198651_112] and later published in Vellozo, Fl.

Flumin. Icon. 2: tab. 109. 1831.

Accepted name: Solanum americanum Mill.

Vellozo might have been using the name $S$. nigrum here in its Linnaean sense, but the taxon depicted in the plate is clearly S. americanum, with pseudoumbellate inflorescences and tiny anthers. The editor of the Index recongised the homonymy and non-identity of these names (Vellozo, 1831a: 10). Sendtner (1846: 16) treated it as a synonym of Solanum nodiflorum Jacq. var. angulosum Sendtn, a synonym of $S$. americanum. Solanum americanum is common in secondary habitats through the coastal areas of São Paulo and Rio de Janeiro states.

Solanum odoriferum Vell., Fl. Flumin. 85. 1829 [1825]; Fl. Flumin. Icon. 2: t. 108. 1831 [1827].

Lectotype (here designated): Brazil. Rio de Janeiro: "habitat silvis maritimis

Pharmacopolitanis"; [illustration] Original parchment plate of Flora Fluminensis in the Manuscript Section of the Biblioteca Nacional, Rio de Janeiro [cat. no.: mss1198651_111] and later published in Vellozo, Fl. Flumin. Icon. 2: tab. 108. 1831 (published plate designated as lectotype by Morton, 1976, pg. 61):.

Accepted name: Solanum odoriferum Vell. 
The distinctive truncate calyx and elliptic leaves depicted in Vellozo's (1831b) illustration make identification of this species unambiguous (Mentz \& Oliveira, 2004). The epithet refers to the fragrant flowers.

Solanum oleraceum Vell., Fl. Flumin. 89. 1829 [1825]; Fl. Flumin. Icon. 2: t. 125. 1831, nom. illeg. non Solanum oleraceum Dunal (1814); = Solanum alternatopinnatum Steud., Nomencl. Bot. 2, 2: 600. 1841. Lectotype (here designated): Brazil. [Rio de Janeiro]: "silvis nondum cultis, tum maritimis, tam mediterraneis habitat"; [illustration] Original parchment plate of Flora Fluminensis in the Manuscript Section of the Biblioteca Nacional, Rio de Janeiro [cat. no.: mss1198651_128] and later published in Vellozo, Fl. Flumin. Icon. 2: tab. 125. 1831 (published plate designated as lectotype by Matesevach Becerra, 2013, pg. 290). Accepted name: Solanum alternatopinnatum Steud.

This species was known for a long time by the name $S$. juciri Mart., a name coined as a replacement for S. oleraceum. Solanum juciri is illegitimate as S. alternatopinnatum was cited in synonymy, with the comment "nomen ineptissimum plantae ab auctore non visae pinni tam alternantibus quam oppositis instructe datum" (this is a silly name given to this plant by the author who did not see alternate but opposite leaflets); Sendtner (1846) recognized the existence of the name but considered it inappropriate.

\section{Solanum paratyense Vell., Fl. Flumin. 90.1829 [1825]; Fl. Flumin. Icon. 2: t. 130. 1831 [1827].}

Lectotype (here designated): Brazil. Rio de Janeiro: “Offendi ad littoral Pitaguaba dicta, trans cautes Cairusú tractu Pharmacopolitano"; [illustration] Original parchment plate of Flora Fluminensis in the Manuscript Section of the Biblioteca Nacional, Rio de Janeiro [cat. no.: mss1198651_133] and later published in Vellozo, Fl. Flumin. Icon. 2: tab. 130. 1831. Accepted name: Solanum jussiaei Dunal

The hooked prickles depicted in Vellozo's (1831b) illustration are typical of this somewhat rare species of the littoral of Rio de Janeiro. The members of this alliance are rarely collected because they are often lianas of the canopy. Sampaio and Peckholt (1937) treat $S$. paratyense as an accepted name and cite Taubert's (1893) treatment of two additional species in synonymy (S. ovalifolium Dunal var. campylacanthum Dunal [a synonym of S. scuticum M.Nee] and S. glaziovii Hiern [a synonym of $S$. jussiaei]).

Solanum perianthomega Vell., Fl. Flumin. 87. 1829 [1825]; Fl. Flumin. Icon. 2: t. 118. 1831, nom utique rej. prop. Lectotype (here designated): Brazil. [Rio de Janeiro]: "silvis maritimis crescit"; [illustration] Original parchment plate of Flora Fluminensis in the Manuscript 
Section of the Biblioteca Nacional, Rio de Janeiro [cat. no.: mss1198651_121] and later published in Vellozo, Fl. Flumin. Icon. 2: tab. 118. 1831.

Accepted name: Athenaea picta (Mart.) Sendtn.

Sampaio \& Peckholt (1937) suggested that this taxon was the same as Solanum megalochiton Sendtn., but it is clear from the plate that it instead refers to a group of species with inflated calyces in the Athenaea/Aureliana complex (Rodrigues \& Stehmann, 2013; Zamberlan \& al., 2015). Both Athenaea picta and A. pogogena (Moric.) Sendtn. occur in the Rio de Janeiro area, but A. pogogena has a distinctly pubescent fruit, not depicted in the plate. We have proposed this name for suppression (Knapp \& al., 2015b).

Solanum repandum Vell., Fl. Flumin. 88. 1829 [1825]; Fl. Flumin. Icon. 2: t. 123. 1831, nom. illeg. non Solanum repandum G.Forst. (1786). Lectotype (here designated): Brazil. [Rio de Janeiro]: "habitat campis apricis"; [illustration] Original parchment plate of Flora Fluminensis in the Manuscript Section of the Biblioteca Nacional, Rio de Janeiro [cat. no.: mss1198651_126] and later published in Vellozo, Fl. Flumin. Icon. 2: tab. 123. 1831. Accepted name: Solanum variabile Mart.

This name was treated by Sendtner (1846: 79) under his description S. variabile with the comment "quod foliis latioribus corollisque profundis partitis depictum" (that depicted with wider leaves and more deeply divided corollas). He did not list this name in the normal position of synonymy (before the description and after the diagnosis), but instead at the end of the description with a question mark indicating his uncertainty over the identity of the plate.

Solanum sericeum Vell., Fl. Flumin. 83. 1829 [1825]; Fl. Flumin. Icon. 2: t. 97. 1831, nom. illeg. non Solanum sericeum Ruiz \& Pav. (1799). Lectotype (here designated): Brazil. [Rio de Janeiro]: “campis mediterraneis"; [illustration] Original parchment plate of Flora Fluminensis in the Manuscript Section of the Biblioteca Nacional, Rio de Janeiro [cat. no.: mss1198651_100] and later published in Vellozo, Fl. Flumin. Icon. 2: tab. 97. 1831. Accepted name: Possibly Solanum capoerum Dunal

As with the preceeding taxon, Sendtner (1846: 45) did not list this name in the normal position of synonymy (before the description and after the diagnosis), but instead at the end of the description of his species S. cinnamomeum Sendtn. with a question mark indicating his uncertainty over the identity of the plate. He commented "huc forsan pertinent" (perhaps pertaining to this species). The plate clearly represents a member of the Brevantherum clade (sensu Weese \& Bohs, 2007), although a precise match would require microscopic analysis of trichome types. Nevertheless, we consider this name more likely to represent $S$. capoerum, a species not treated by Sendtner, due to the conspicuous and dense indumentation represented in the adaxial leaf surfaces that is not observed 
in other species such as S. itatiaiae Dusén or S. sellowianum Sendtn. (Giacomin, 2015). The habitat cited by Vellozo - "campis mediterraneis" - that refers to open areas at higher elevations (Lima, 1995) is also the habitat of S. capoerum, whose type is from "Serra dos Orgãos".

Solanum sinuatifolium Vell., Fl. Flumin. 91. 1829 [1825]; Fl. Flumin. Icon. 2: t. 132. 1831 [1827].

Lectotype (here designated): Brazil. [Rio de Janeiro]: "habitat mediterraneis et maritimis";

[illustration] Original parchment plate of Flora Fluminensis in the Manuscript Section of the Biblioteca Nacional, Rio de Janeiro [cat. no.: mss1198651_135] and later published in Vellozo, Fl. Flumin. Icon. 2: tab. 132. 1831.

Accepted name: Solanum capsicoides All.

Sendtner (1846: 59) treated this (along with $S$. arrebenta) as a synonym of S. aculeatissimum, under which he grouped many names now referring to various species of section Acanthophora (see Nee, 1974). Considerable confusion over the identity of these species, all of which are native in southeastern Brazil, existed until Nee (1974) established the identity of these taxa and re-established use of $S$. capsicoides, rather than S. ciliatum Lam. but which name they were long known, for these Brazilian plants.

Solanum stipulatum Vell., Fl. Flumin. 87. 1829 [1825]; Fl. Flumin. Icon. 2: t. 116. 1831 [1827].

Lectotype (here designated): Brazil. [Rio de Janeiro]: “campis apricis mediterraneis"; [illustration] Original parchment plate of Flora Fluminensis in the Manuscript Section of the Biblioteca Nacional, Rio de Janeiro [cat. no.: mss1198651_120] and later published in Vellozo, Fl. Flumin. Icon. 2: tab. 116. 1831 (published plate designated as lectotype by Knapp, 2002, pg. 340).

Accepted name: Solanum stipulatum Vell.

Sendtner specifically rejected Vellozo's plate of Solanum stipulatum as "icon mala" (Sendtner, 1846: 25) and treated this as a synonym of his new Solanum rivulare. In fact, as pointed out in Knapp (2002) the plate is an accurate, if somewhat stylized depiction of this species. Sampaio \& Peckolt (1943) pointed out that Vellozo's name had priority.

Solanum subscandens Vell., Fl. Flumin. 90. 1829 [1825]; Fl. Flumin. Icon. 2: t. 128. 1831 [1827].

Lectotype (here designated): Brazil. [Rio de Janeiro]: "habitat silvis maritimis et mediterraneis"; [illustration] Original parchment plate of Flora Fluminensis in the Manuscript Section of the Biblioteca Nacional, Rio de Janeiro [cat. no.: mss1198651_131] and later published in Vellozo, Fl. Flumin. Icon. 2: tab. 128. 1831 (published plate designated as lectotype by Agra, 2004, pg. 201).

Accepted name: Solanum cordifolium Dunal 
Sendtner (1846) accepted S. subscandens as did Sampaio and Peckolt (1943). Agra (2004) in her synopsis of section Erythrotrichum Child listed it as a synonym of $S$. cordifolium citing the sinuate leaf margins characteristic of that species that are apparent in the Vellozo illustration.

Solanum subumbellatum Vell., Fl. Flumin. 85. 1829 [1825]; Fl. Flumin. Icon. 2: t. 105. 1831 [1827].

Lectotype (here designated): Brazil. [Rio de Janeiro]: "habitat campis apricis

mediterraneis"; [illustration] Original parchment plate of Flora Fluminensis in the Manuscript Section of the Biblioteca Nacional, Rio de Janeiro [cat. no.: mss1198651_108] and later published in Vellozo, Fl. Flumin. Icon. 2: tab. 105. 1831.

Accepted name: Solanum subumbellatum Vell.

This is the name that has long been used for a common species of spiny Solanum found all over southern Brazil. Although the illustration, like all the rest, is highly stylized, its identity is relatively clear. An epitype should be designated to aid with interpretation, but we feel this should be done in the context of monographic revision of the group to which this species belongs.

Solanum tabaccifolium Vell., Fl. Flumin. 81. 1829 [1825]; Fl. Flumin. Icon. 2: t. 89. 1831 [1827].

Lectotype (here designated): Brazil. [Rio de Janeiro]: "maritimis aeque, ae mediterraneis praecipue silvis recentur excultis crescit"; [illustration] Original parchment plate of Flora Fluminensis in the Manuscript Section of the Biblioteca Nacional, Rio de Janeiro [cat. no.: mss1198651_092] and later published in Vellozo, Fl. Flumin. Icon. 2: tab. 89. 1831.

Accepted name: Solanum mauritianum Scop.

Sendtner (1846) treated this as a synonym of Solanum auriculatum Ait., the name by which $S$. mauritianum was previously known and over which $S$. mauritianum has priority.

Solanum terminale Vell., Fl. Flumin. 84. 1829 [1825]; Fl. Flumin. Icon. 2: t. 101. 1831, nom. illeg. non Solanum terminale Forssk. (1775). Lectotype (here designated): Brazil. [Rio de Janeiro]: "habitat campis apricis mediterraneis prope Pagum Cunha"; [illustration] Original parchment plate of Flora Fluminensis in the Manuscript Section of the Biblioteca Nacional, Rio de Janeiro [cat. no.: mss1198651_104] and later published in Vellozo, Fl. Flumin. Icon. 2: tab. 101. 1831.

Accepted name: Solanum itaitaie Dusén

Sendtner (1846: 34) treated this name as a synonym of his $S$. isodynamum Sendtn., now considered an highly restricted range species only known from the hills of Minas Gerais (Giacomin, 2015). He also treated S. terminale Vell. as a synonym of S. subumbellatum (Sendtner 1846: 79); both citations were accompanied by question marks. From the locality citation, description and narrow 
leaves in the illustration it is more likely this name refers to the high elevation $S$. itaitaiae, known from the Cunha region.

\section{Solanum triphyllum Vell., Fl. Flumin. 88. 1829; Fl. Flumin. Icon. 2: t. 120. 1831 [1827]. Lectotype}

(here designated): Brazil. [Rio de Janeiro]: "habitat campis medirraneis trans-alpinis. Offendi ad viam prope aediculam Praedii vulgo dicti Boavista"; [illustration] Original parchment plate of Flora Fluminensis in the Manuscript Section of the Biblioteca Nacional, Rio de Janeiro [cat. no.: mss1198651_123] and later published in Vellozo, Fl. Flumin. Icon. 2: tab. 120. 1831 (published plate designated as lectotype by Knapp, 2013, pg. 143). Accepted name: Solanum flaccidum Vell.

Knapp (2013) did not accept the synonymy proposed by Sendtner (1846), who placed this name in the synonymy of $S$. prunifolium Willd. (a synonym of the cultivated $S$. seaforthianum Andrews). The large flowers and dimorphic leaves suggest a young plant of S. flaccidum. It could, however, be either species, S. seaforthianum is known from this region usually in cultivation, but is naturalised in many tropical and subtropical parts of the world. The oldest Brazilian specimen cited in Knapp (2013) for S. seaforthianum is from the island of Fernando de Noronha (Ridley \& al. 69, coll. 1887); S. seaforthianum was not in common cultivation in southern Brazil at the time Vellozo was collecting for Flora Fluminensis.

Solanum uniflorum Vell., Fl. Flumin. 86. 1829 [1825]; Fl. Flumin. Icon. 2: t. 114. 1831, nom. illeg. non Solanum uniflorum Dunal (1814). Lectotype (here designated): Brazil. [Rio de Janeiro]: "habitat campis mediterraneis prope praedium Boavista"; [illustration] Original parchment plate of Flora Fluminensis in the Manuscript Section of the Biblioteca Nacional, Rio de Janeiro [cat. no.: mss1198651_117] and later published in Vellozo, Fl. Flumin. Icon. 2: tab. 114. 1831 (published plate designated as lectotype by Knapp, 2002, pg. 62).

Accepted name: Solanum pseudocapsicum L.

This name has been accepted as a synonym of Solanum pseudocapsicum by many authors (Sendtner, 1846; Sampaio \& Peckolt, 1943; Knapp, 2002; Mentz \& Oliveira, 2004).

\section{ACKNOWLEDGEMENTS}

We thank the many funding agencies that have enabled us to come together to work out these problems and our respective institutions for supporting our taxonomic work in Solanaceae over many years. JRS and LLG were supported by FAPEMIG (APQ-01706-13), CNPq (479921/2010-5, 148363/2010-5; 309304/2013-0) and the Rede Integrada em Taxonomia de Plantas e Fungos through the SISBIOTA program (563342/2010-2); an IAPT fellowship funded herbarium visits by LLG; SK was supported by NSF (DEB-0316614 "PBI Solanum: A worldwide treatment"), INCT-Herbário 
Virtual da Flora e dos Fungos and FAPESP; GEB was funded by grants from SECyT (UNC), CONICET (PID 00552) y FONCYT (PICT 2775). We also thank Kevin Webb (NHM Photographic Unit) for photographing Vellozo illustrations for use on Solanaceae Source (www.solanaceaesource.org) with permission of the Natural History Museum Library and referred to in this paper; and L.A. Mentz for advice on the identity of many of these species. Two anonymous reviewers and J. Prado provided helpful comments that greatly improved the manuscript.

\section{LITERATURE CITED}

Agra, M. de F. 2004. Sinopse taxonomica de Solanum sect. Erythrotrichum (Solanaceae). VIII Congreso Latinoamericano y II Colombiano de Botanica: Bogotá, pp. 192-211.

Bentham, G. 1846. Scrophulariaceae: Brunfelsia. In A.P. de Candolle (ed.) Prodromus Systematis Naturalis Regni vegetabilis 10: 198-201, 590-591.

Bernardello, L.M. [G.] and Hunziker, A.T. 1987. A synoptical revision of Solandra (Solanaceae). Nordic J. Bot. 7: 639-652.

Boehmer, G.R. 1760. Definitiones generum plantarum (by Christian Gottlieg Ludwig), edition 3. Leipzig: J.F. Gleditsch.

Bohs, L. 1994. Cyphomandra (Solanaceae). Fl. Neotrop. 63: 1-175.

Bohs, L. 2001. Solanum section Cyphomandropsis. Syst. Bot. Monogr. 61: 1-85.

Bohs, L. 2007. Phylogeny of the Cyphomandra clade of the genus Solanum (Solanaceae) based on ITS sequence data. Taxon 56(4): 1012-1026.

Carauta, J.P.P. 1969. A data efetiva da publicação da "Flora Fluminensis". Vellozia 7: 3-21.

Carauta, J.P.P. 1973. The text of Vellozo's Flora fluminensis and its effective date of publication. Taxon 22: 281-284.

Carvalho, L.D.F. de 1978. O gênero Schwenckia D. van Rooyen ex Linnaeus no Brasil (Solanaceae). Rodriguesia 44: 307-522.

Carvalho, L.D.F. de 1996. Espécies de Solanum das Seções Cernuum Carv. e Sheph. e Lepidotum (Dun.) Seithe v.Hoff (Solanaceae). Pesquisas, Bot. 46: 5-83.

Chiarini, F.E. 2013. Grupo II. Cyphomandra. In A.M. Anton \& F.O. Zuloaga (eds.), G.E. Barboza (coord.) Flora Argentina vol. 13, Solanaceae, pp. 166-175. IBODA- IMBIV, CONICET: Buenos Aires \& Córdoba, Argentina. 
Chiarini, F.E. 2013. Grupo VI. Leptostemonum. In A.M. Anton \& F.O. Zuloaga (eds.), G.E. Barboza (coord.) Flora Argentina vol. 13, Solanaceae, pp. 206-231. IBODA- IMBIV, CONICET: Buenos Aires \& Córdoba, Argentina

Cocucci, A.A. 2013. Nicotiana. In A.M. Anton \& F.O. Zuloaga (eds.), G.E. Barboza (coord.) Flora Argentina vol. 13, Solanaceae, pp. 75-89. IBODA- IMBIV, CONICET: Buenos Aires \& Córdoba, Argentina.

Dunal, M.-F. 1852. Solanaceae. In A.P. de Candolle (ed.) Prodromus Systematis Naturalis Regni vegetabilis 13 (1): 1-690.

Giacomin, L.L. 2015. Solanum L. clado Brevantherum (Solanaceae): Sistemática e Diversidade. Ph.D. dissertation, Universidade Federal de Minas Gerais, Belo Horizonte, Minas Gerais, Brazil.

Handro, O. 1953. III. - Novedades taxonomicas de J.F. Toledo. Arq. Bot. Estado São Paulo n.s., form. maior 3: 63-97.

Hunziker, A.T. 2000. The genera of Solanaceae: The genera of Solanaceae arranged, according to a new system. Ruggell: A.R.G. Gantner Verlag.

Hunziker, A.T. \& Barboza, G.E. 1991. Estudios sobre Solanaceae XXX. Revisión de Aureliana. Darwiniana 30: 95-113.

Knapp, S. 2002. Solanum section Geminata (G.Don) Walp. (Solanaceae) Fl. Neotrop. 84: 1-405.

Knapp, S. 2013. A revision of the Dulcamaroid Clade of Solanum L. (Solanaceae). PhytoKeys 22: 1403.

Knapp, S., Stehmann, J.R. \& Giacomin, L.L. 2015a. New species, additions and a key to the Brazilian species of the Geminata clade of Solanum L. (Solanaceae) in Brazil. PhytoKeys 47: $1-48$.

Knapp, S., Barboza, G.E., Giacomin, L.L. \& Stehmann, J.R. 2015b. (xxxx-xxxx) Proposal to reject the names Cestrum subsessile, Solanum ambrosiacum, S. coronatum, $S$. diantherum, S. jubeba, S. multiangulatum and S. perianthomega (Solanaceae) from Vellozo's Flora Fluminensis. Taxon 64: in press.

Lima, H.C. de 1995. Leguminosas da Flora Fluminensis - J.M. da C. Vellozo - Lista actualizada da espécies arbóreas. Acta Bot. Bras. 9: 123-146.

Macbride, J.F. 1930. Peruvian Solanaceae. Publ. Field Mus. Nat. Hist., Bot. Ser. 8: 105-112.

Matesevach Becerra, M. 2013. Grupo IX. Solanum wendlandii. In A.M. Anton \& F.O. Zuloaga (eds.), G.E. Barboza (coord.) Flora Argentina vol. 13, Solanaceae, p. 290. IBODA- IMBIV, CONICET: Buenos Aires \& Córdoba, Argentina 
Mentz, L.A. \& Oliviera P.L. de 2004. Solanum (Solanaceae) na região sul do Brasil. Pequisas, Bot. 54: $1-327$.

Moricand, M.É. 1837. Plantes nouvelles d'Amerique, livr. 3. Geneva: Jules Guillaume Fick.

Morton, C. V. 1957. Some South American species of Solanum. Contr. U.S. Natl. Herb. 29: 41-72.

Morton, C.V. 1976. A revision of the Argentine species of Solanum. Cordoba, Argentina: Academia Nacional de Ciencias.

Muller Argoviensis, J. 1860. Apocynaceae, Allamandiae. In C. Martius (ed.), Flora Brasiliensis 6 (1): $1-196$.

Nee, M. 1974. A revision of Solanum section Acanthophora. PhD thesis, University of Wisconsin, Madison, Wisconsin, USA.

Pastore, J.F.B. 2013. A review of Vellozo's names for Polygalaceae in his Flora Fluminensis. Phytotaxa 108 (1): 41-48.

Paula-Souza, J de \& Ballard, H.E. Jr. 2014. Re-establishment of the name Pombalia, and new combinations from the polyphyletic Hybanthus (Violaceae). Phytotaxa 183: 1-15.

Pelligrini, M.O. de O., Forzza, R.C. \& Sakuragui, C.M. 2015. A nomenclatural and taxonomic review of Tradescantia (Commelinaeae) species described in Vellozo's Flora fluminensis with notes on Brazilian Tradescantia. Taxon 64: 151-155.

Plowman, T.C. 1998. A revision of the South American species of Brunfelsia (Solanaceae) [ed. S. Knapp \& J.R. Press]. Fieldiana, Bot. n.s. 39: 1-135.

Rodrigues, I.M.C. \& Stehmann, J.R.. 2013. Aureliana. In A.M. Anton \& F.O. Zuloaga (eds.), G.E. Barboza (coord.) Flora Argentina vol. 13, Solanaceae, pp. 135-136. Buenos Aires \& Córdoba, Argentina: IOBDA- IMBIV, CONICET.

Roemer, J.J. \& Schultes, J.A. 1819. Systema vegetabilium 4: 1-888.

Sampaio, A.J. \& Peckholt, O. 1943. A nomeclatura das espécies na "Flora Fluminensis" de Conceicao Veloso e sua correspondicia atual. Arq. Mus. Nac. 43: 333-394.

Särkinen, T., Bohs, L., Olmstead, R.G. \& Knapp, S. 2013. A phylogenetic framework for evolutionary study of the nightshades (Solanaceae): a dated 1000-tip tree. B. M. C. Evol. Biol. 13: 214 .

Schmidt, J.A. 1862. Scrophularinae. In C. Martius (ed.), Flora Brasiliensis 8: 227-330.

Sendtner, O. 1845. Monographia Cyphomandrae: novi Solanacearum generis. Flora 28: 161-176 (1 plate).

Sendtner, O. 1846. Solanaceae. In C. Martius (ed.), Flora Brasiliensis 10: 5-338 
Soares, E.L.C., Vignoli-Silva, M. \& Mentz, L.A. 2007. O gênero Cestrum (Solanaceae) no Rio Grande do Sul, Brasil. Pesquisas, Bot. 58:263-282.

Stehmann, J.R., Mentz, L.A., Agra, M.F., Vignoli-Silva, M., Giacomin, L., Rodrigues, I.M.C. 2014. Solanaceae in Lista de Espécies da Flora do Brasil. Jardim Botânico do Rio de Janeiro. <http://www.floradobrasil.jbrj.gov.br/jabot/floradobrasil/FB225>. Accessed on 14 Dec. 2014

Stellfeld, C. 1946. A toponimia latina da "Flora Fluminensis". Tribuna. Farm. 14(12): 246-248.

Vellozo, J.M.da C. 1829 [1825]. Florae fluminensis. Typographia Nacionali: Rio de Janeiro.

Vellozo, J.M. da C. 1831a [1827]. Index methodicus iconorum Florae Fluminensis. Florae fluminensis. Icones 11: 1-14. Senefleder: Paris.

Vellozo, J.M. da C. 1831b [1827]. Florae fluminensis. Icones 2: figs.1-156. Paris: Senefleder.

Vellozo, J.M. da C. 1881. Florae fluminensis, Arch. Mus. Nac. Rio de Janeiro 5: 1-461.

Vignoli-Silva, M. 2009. O gênero Cestrum L. (Solanaceae) no Brasíl extra-amazonico. Ph.D. dissertation, Universidade Federal do Rio Grande do Sul, Porto Alegre, Rio Grande do Sul, Brazil.

Zamberlan, P.M., Rodrigues, I.M.C., Mäder, G., Castro, L., Stehmann, J.R., Bonatto, S.L. \& Freitas, L.B. 2015. Re-evaluation of the generic status of Athenaea and Aureliana (Withaninae, Solanaceae) based on molecular phylogeny and morphology of the calyx. Bot. J. Linn. Soc. 177: 322-334. 